\title{
Rancang Bangun Game Android Adventure Finding Diamond Dengan Unity 3D Menggunakan Metode Dynamic Weighting A*
}

\author{
Nahdia Asri Umami ${ }^{1}$, Ina Agustina ${ }^{2}$, Fauziah $^{3}$ \\ ${ }^{1}$ nahdiaarumi@gmail.com, ${ }^{2}$ ina.agustina@civitas.unas.ac.id, ${ }^{3}$ fauziah@citivas.unas.ac.id
}

Program Studi Teknik Informatika, Fakultas Teknologi Komunikasi dan Informatika, Universitas Nasional

\begin{abstract}
One of the most popular games is game adventure genre. The process and game design begins with the storyline design. In game development there are some software needed to develop the game such as unity $3 d$. Unity $3 D$ itself is a tool that integrates to create games ranging from building architecture and simulation. Unity can be used for making games that can be used on android devices. Android is growing very rapidly in the smart phone market in the world. Based on the results of the study, a suitable Dynamic Weighting $A$ * method is implemented in Game Advanture that recognizes the arena environment and does not happen the same random scramble at the time the application is reopened.
\end{abstract}

Abstrak- Salah satu jenis game yang digemari adalah game bergenre adventure game.proses dan perancangan game dimulai dengan menggunakan desain alur cerita. Dalam pengembangan game ada beberapa software yang diperlukan untuk perangan mengembangkan game seperti unity 3d. Unity 3D sendiri adalah sebuah tool yang terintregasi untuk membuat game mulai dari arsitektur bangunan dan simulasi. Unity dapat digunakan untuk pembuatan game yang bisa digunakan pada perangkat android. Android berkembang sangat pesat di pasaran ponsel pintar di dunia. Berdasarkan hasil penelitian, metode Algoritma Dynamic Weighting A*cocok diimplementasikan pada Game Advanture yang mengenal lingkungan arena dan tidak terjadi perulangan pengacakan yang sama pada saat aplikasi dibuka kembali.Dari hasil penelitian yang dilakukan menggunakan kuesioner

Kata Kunci : Algoritma Dynamic Weighting $\mathbf{A}^{*}$, Advanture game, Unity 3D, Android

\section{PENDAHULUAN}

Finding Diamond merupakan sebuah game [1][2][3] yang dapat dimainkan semua kalangan dimana permainan ini menekan kepada pemainnya untuk menyelesaikan. permainan, karena didalam permainan finding diamond akan ada banyak rintangan yang harus dihadapi untuk memperoleh diamond. Game ini akan mengajak pemain menjelajah dan berpetualang [4][5][6][7][8] yang berbeda disetiap levelnya. Game merupakan salah satu media hiburan yang menjadi pilihan masyarakat untuk menghilangkan kejenuhan atau hanya untuk sekedar mengisi waktu luang. Dalam pembuatan game bergenre tentunya membutuhkan software yang digunakan untuk membuat game, saat ini banyak software yang memiliki kualitas dan fitur yang sangat canggih untuk membuat game.Unity 3D merupakan game engine yang berbasis cross-platform. Unity [11] 3d merupakan software yang digunakan untuk mengembangkan game multi platform [17] yang didesain. Unity dapat digunakan untuk membuat video game 3D [12][13][14][19], animasi realtime 3D dan visualisasi arsitektur. Hasil Penelitian yang didapat pada perancangan dan pembuatan game advanture $[10[15[16][18]$ ]finding diamond berbasis android yang melakukan proses searching data dan tampilan game yang dihasilkan berupa diamond.

Penelitian ini membahas perancangan sebuah game yang dibuat untuk single player, dapat dimainkan secara offline. Game dibangun dengan menggunakan unity 3D. Tujuan rancangn bangun game dalam penelitian ini adalah sebagai sarana hiburan dan media pembelajaran [9] untuk melatih kecerdasan dan ketelitian terhadap suatu kondisi dan dapat digunakan untuk melatih kreatifitas anak dalam berexplorasi didalam kesulitan

\section{METODOLOGI PENELITIAN}

Algoritma Dynamic Weighting

Algoritma Dynamic Weighting A* (A Star) merupakan pengembangan dari algoritma $A^{*}$. Algoritma ini bertujuan untuk melakukan pencarian kesegala arah pada awal iterasi dan ketika goal state sudah dekat baru pencarian difokuskan ke arah goal state merupakan karakterisitik dari algoritma dan penerapan algoritma dynamic weighting ini akan diterapkan dalam penyebaran titik untuk penempatan diamond disetiap level. Untuk itu digunakan juga pembobotan yang dinamis.

$\mathbf{f}(\mathbf{n}) \quad=\mathbf{g}(\mathbf{n})+(\mathbf{w}(\mathbf{n}) * \mathbf{h}(\mathbf{n}))$

Dengan :

$\mathrm{f}(\mathrm{n}) \quad=$ hasil perhitungan dari $\mathrm{g}(\mathrm{n}), \mathrm{h}(\mathrm{n})$, dan $\mathrm{w}(\mathrm{n})$

$\mathrm{n} \quad=$ simpul saat ini

$\mathrm{g}(\mathrm{n}) \quad=$ biaya $($ cost $)$ dari simpul awal ke simpul $\mathrm{n}$ sepanjang jalur pencarian

$\mathrm{h}(\mathrm{n})=$ perkiraan cost dari simpul $\mathrm{n}$ ke simpul tujuan (nilai heuristik)

$\mathrm{w}(\mathrm{n})=$ bobot dinamis

Perancangan Aplikasi

Perancangan aplikasi menggunakan spesifikasi hardware dan software adalah Bahasa Pemrograman C\# dan Javascript, Game Engine Unity 3D, Software Model 3D Blender, Sistem Operasi Windows 8. Spesifikasi komputer yang digunakan Processor : Intel(R) Celeron(R) CPU 1007U @ 1.50GHz, RAM : 4096 GB (1.89 GB usable) 


\section{Kerangka Penelitian}

Berikut ini adalah tampilan kerangka penelitian finding diamond game.

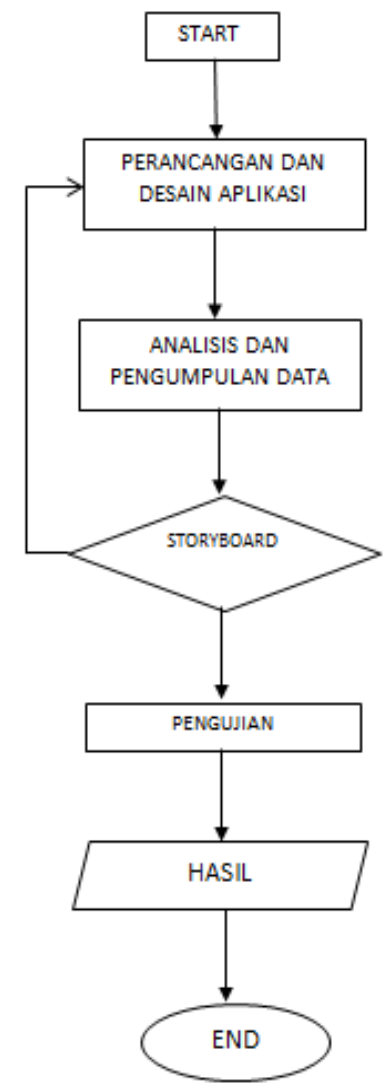

Gambar 1. Flow Chart Kerangka Penelitian

\section{Perancangan Menu/Site Map}

Berikut ini adalah perancangan tampilan finding diamond game yang dibangun.

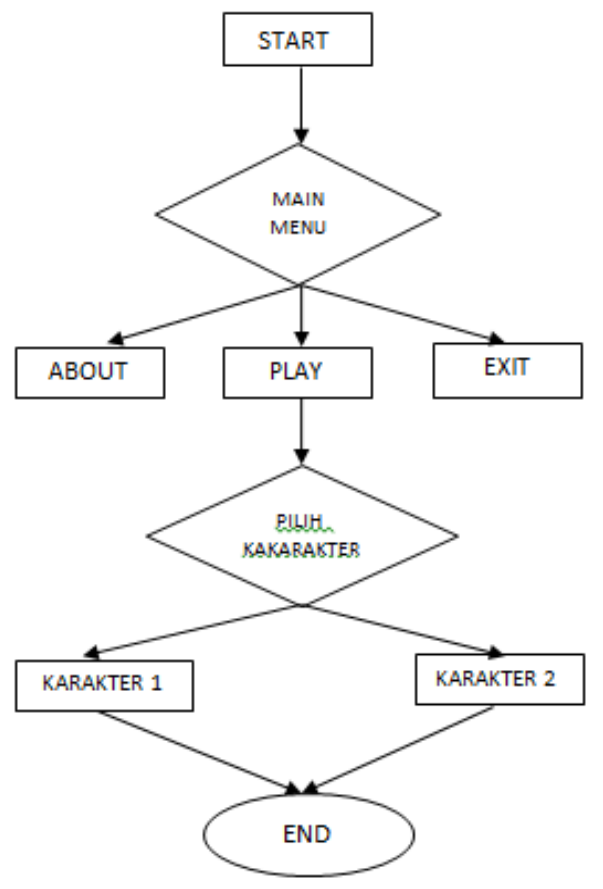

Gambar 2. Flow Chart Perancangan Game

Game ini dibangun dengan target pengguna untuk semua kalangan mulai dari anak-anak hingga dewasa. Aplikasi ini merupakan sebuah game android yang dapat memberikan kontribusi kepada masyarakat dan anak-anak. Game ini memiliki spesifikasi sebagai Game yang dibuat berjenis adventure game berbentuk 3 dimensi. Game dapat dijalankan pada android. Game bersifat single player

Dalam penelitian ini pengguna harus dapat melakukan pencarian diamond pada setiap levelnya dan dapat memilih karakter laki-laki dan perempuan untuk memainkan game, di dalam game ini memiliki 3 level yaitu pada level pertama harus melakukan pencarian diamond dan melewati rintangan dengan karakter yang telah dipilih. Pencarian diamond ini dibatasi dengan 5 pencarian disetiap level dimana ketika user mendapatkan 1 diamond dalam setiap level sudah bisa menang. Namun bila dalam pencarian diamond

Tabel 1.

Storyboard Aplikasi

\begin{tabular}{|l|l|}
\hline Desain & \multicolumn{1}{|c|}{ Keterangan } \\
\hline Splash Screen \\
\hline ind
\end{tabular}

\section{HASIL DAN PEMBAHASAN}

\section{Implementasi}

Implementasi ini merupakan tahapan untuk mengubah hasil dari rancangan system yang telah disusun berdasarkan Alur dan Storyboard menjadi bentuk nyata, dalam hal ini berupa aplikasi game yang berjalan pada platform android. Pemilihan pembuatan game ini bertujuan untuk mengembangkan game. Berikut ini adalah hasil implementasi rancang bangun game. Splash Screen merupakan tampilan awal pembuka aplikasi permainan yang sedang berjalan dapat dilihat pada Gambar 4. Pada Tampilan berikutnya adalah Tap To Start merupakan tampilan pilihan untuk menuju ke main menu seperti yang disajikan pada Gambar 5. Tampilan Main Menu pada Gambar 6 merupakan tampilan 
utama dari aplikasi games ini. Di dalam halaman menu utamaini terdiri dari beberapa tombol yang diakses untuk pengguna, yaitu button" play", “About", "Exit".

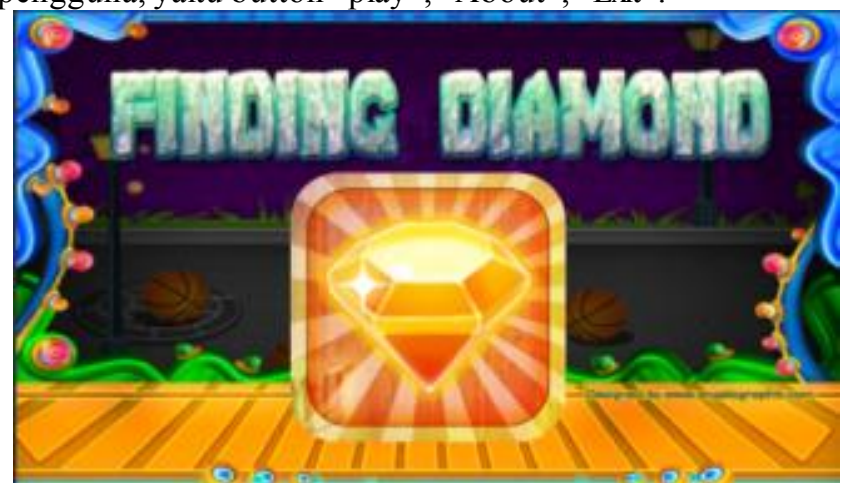

Gambar 4. Splash Screen

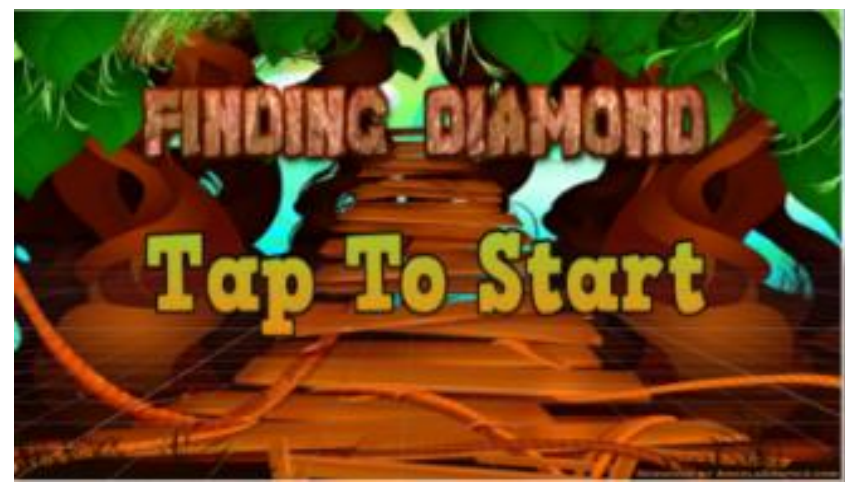

Gambar 5. Tap To Start

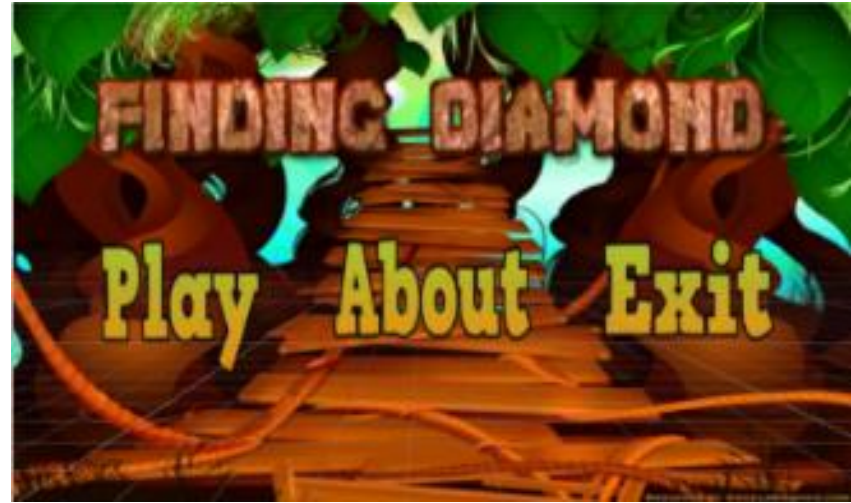

Gambar 6. Main Menu

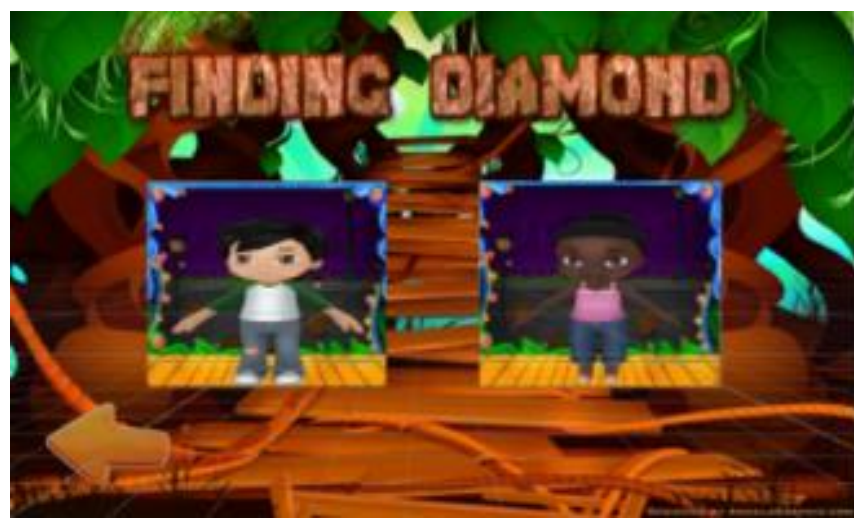

Gambar 7.Pemilihan Karakter

Pada form ini, user dapat memilih karakter yang akan diamainkan. Dalam form ini tedapat 2 tokoh karakter dan terdapat tombol back yang berfungsi untuk kembali ke main menu. Pada tampian scene level 1 merupakan tampilan permainan tahap awal yang dimana user harus memasuki area labirin, dan harus mencari diamond yang telah di tempatkan pada titik tertentu serta harus menghindari jebakan yang telah disiapkan.

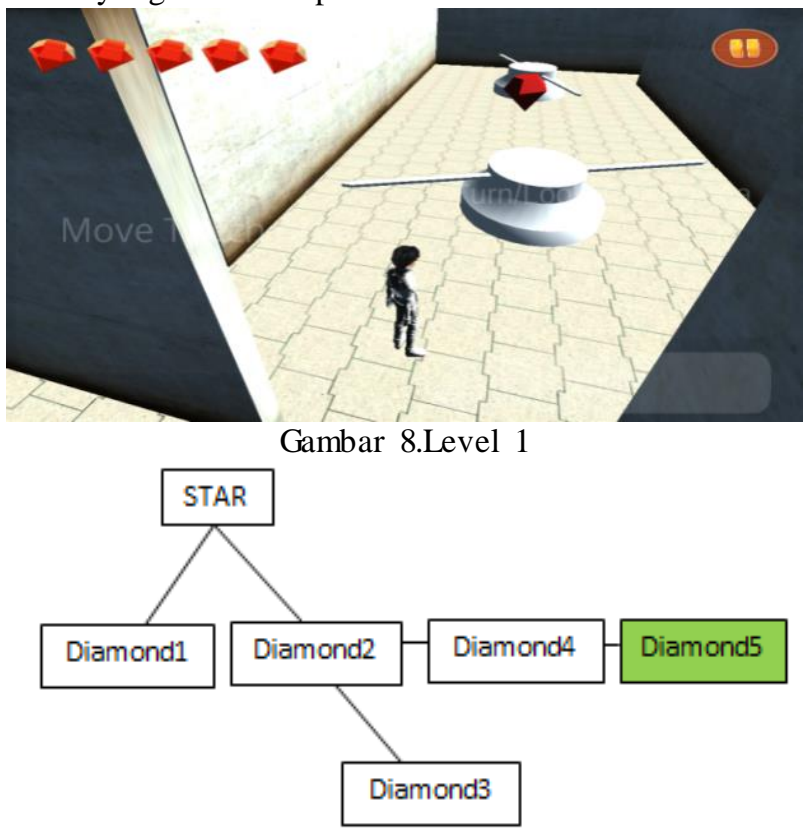

Gambar 9. Skema DW A* Level 1

Pada level ini user minimal harus mendapatkan satu diamond untuk bisa melanjutkan ke level selanjutnya. Apabila terkena jebakan pada level ini maka permainan akan mengulang dari awal. Dalam level 1 ini diterapkan Algoritma Dynamic Weighting $A^{*}$ untuk penyebaran titik-titik penempatan diamond yang telah ditentukan, dan penemuan goal state atau finish yang ditandai dengan warna hijau yang menandakan bahwa goal state sudah dekat. Penerapannya adalah seperti pada Gambar 9

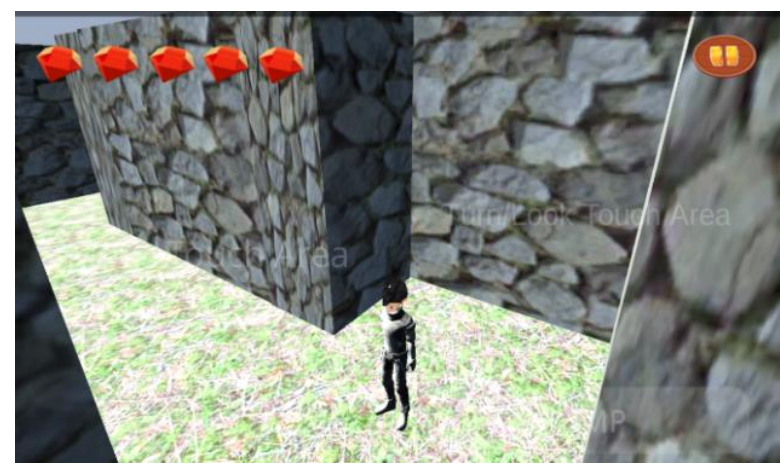

Gambar 10. Level 2

Pada tampilan scene level 2 merupakan tampilan permainan tahap kedua, pada level 2 ini tidak jauh berbeda dengan level 1 , hanya saja ada beberapa perbedaan yaitu pada tingkat kesulitan dilevel ini ditambah dengan adanya area labirin untuk pencarian diamond serta arah menuju finish lebih dibuat sedikit rumit. 


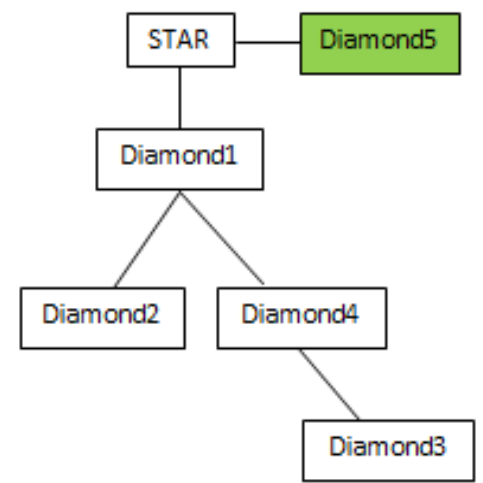

Gambar 11. Skema DW A* Level 2

Namun berbeda dengan level 1 penerapan Algoritma Dynamic Weighting $A^{*}$ untuk penyebaran titik-titik penempatan diamond dan penerapan goal state yang ditandai dengan warna yang sama yaitu hijau bahwa goal state yang dituju sudah dekat. Berikut adalah penerapan penyebaran pada level 2 seperti pada Gambar 11 dibawah ini.

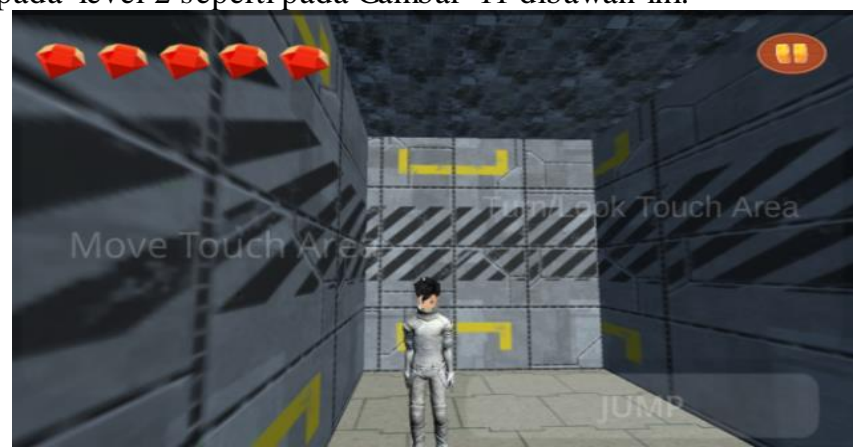

Gambar 12. Level 3

Pada tampilan scene level 3 merupakan tampilan permainan tahap ketiga, pada level 3 ini juga prinsipnya sebenarnya masih sama dengan level $1 \& 2$ yaitu untuk mecari diamond, Dimana tingkat kesulitan dilevel 3 ini adalah penggabungan dari tingkat kesulitan pada level 1 dan kesulitan di level 2, yaitu dengan memperbanyak jebakan dan penambahan area labirin. Pada level 3 ini penerapan Algoritma Dynamic Weighting $A^{*}$ untuk penyebaran titiktitik penempatan diamond adalah sebagai berikut :

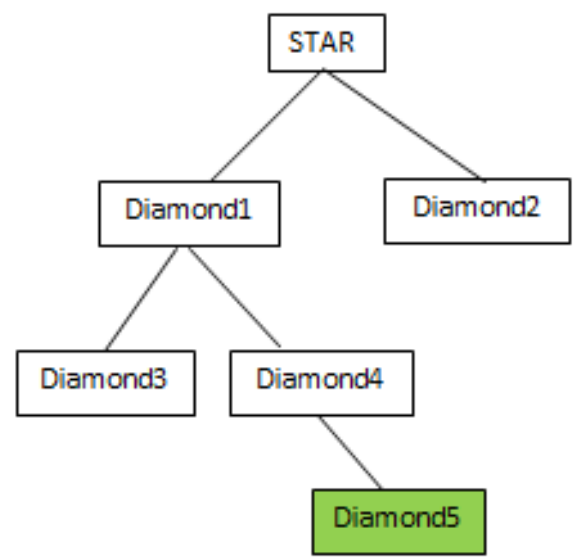

Gambar 13. Skema DW A* Level 3

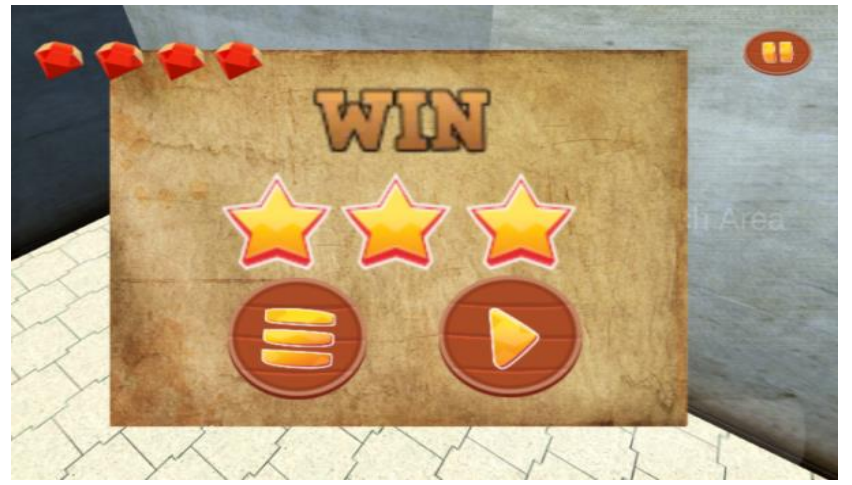

Gambar 13. Tampilan Pemenang (Win)

Tampilan Gambar 13 merupakan tampilan apabila user menyelesaikan finish, dan akan muncul button untuk kembali ke menu awal dan button untuk melanjutkan game berikutnya.

Tampilan scene pada Gambar 14 merupakan tampilan game over apabila user terkena jebakan, dan akan muncul button untuk kembali ke menu awal dan button untuk try again untuk memulai kembali game tersebut.

Tampilan scene pada Gambar 15 merupakan tampilan pause apabila user ingin menjeda permainan saat sedang berjalan, dan akan muncul button untuk kembali ke menu awal,button play untuk memulai game yang dijeda dan button try again untuk memulai game dari awal.

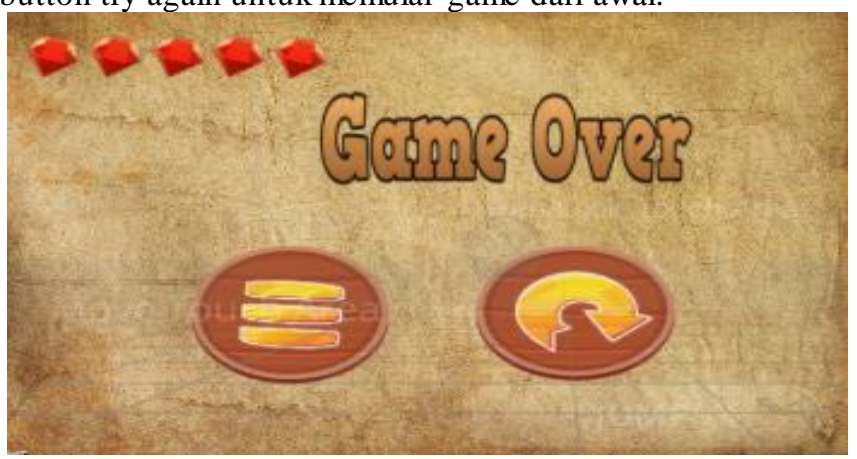

Gambar 14. Tampilan Game Over

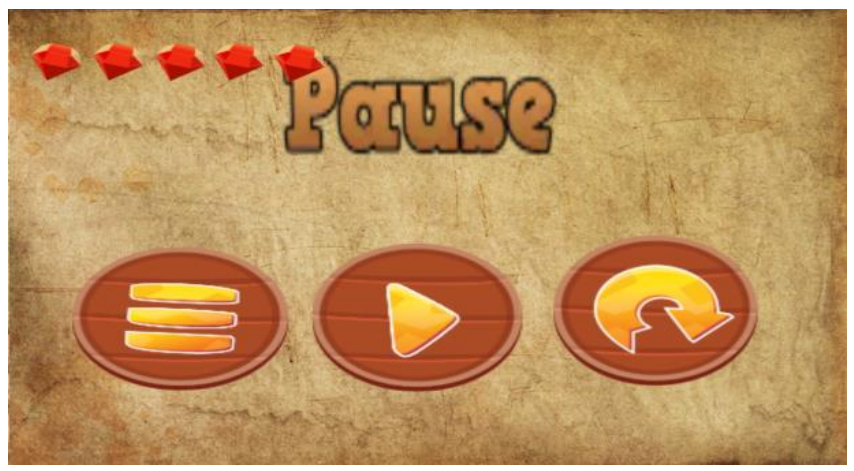

Gambar 15. Tampilan Pause

\section{Pengujian Game}

Dalam analisis pengujian sistem dilakukan menggunakan dua smartphone dengan sistem operasi android. Untuk smartphone memiliki spesifikasi lebih rendah daripada smartphone kedua. Pengujian ini dilakukan untuk mengetahui fungsi aplikasi pada smartphone.

Tabel 2.

Spesifikasi Smartphone

\begin{tabular}{|l|c|c|}
\hline & Smartphone 1 & Smartphone 2 \\
\hline Merk & Samsung Grand & Xiaomi \\
\hline
\end{tabular}




\begin{tabular}{|l|c|c|}
\hline & Prime & \\
\hline RAM & $2 \mathrm{~GB}$ & $2 \mathrm{~GB}$ \\
\hline Sistem & Lolipop & Marshmallow \\
\hline
\end{tabular}

\section{Pengujian Tingkat Kecepatan Di Smartphone}

Dari Pengujian dibawah, bahwa tingkat kecepatan masing-masing smartphone memiliki tingkat kecepatan yang berbeda namun kecepatan yang paling baik untuk game ini menggunakan smartphone yang berspesifikasi tinggi. Seperti yang ditunjukkan pada Gambar 16.

\section{Pengujian Black Box}

Pengujian Black Box bertujuan mengetahui fungsi perangkat lunak dalam pengoperasian game dan hasil uji blackbox dari game seperti yang ditunjukkan pada Gambar 17. Berdasarkan tabel hasil uji coba blackbox, virtual button yang digunakan berjalan sesuai yang diharapkan oleh user atau pengguna.

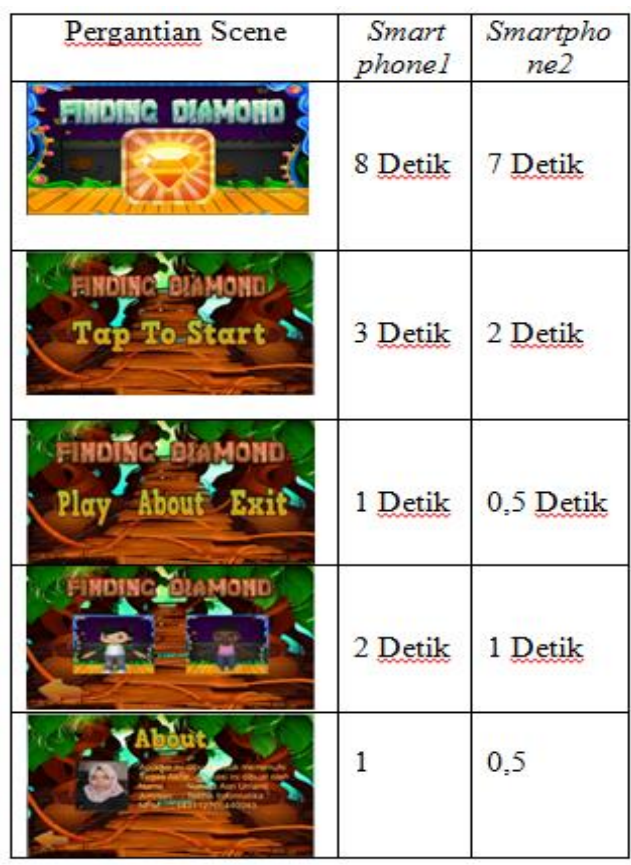

Gambar 16. Pengujian Storyboard

\begin{tabular}{|l|l|l|l|l|}
\hline No & Pengujian & Input & Output & Kesimpulan \\
\hline 1 & Start Game & Klik mulai bermain & Mulai Bermain & $\begin{array}{l}\text { Tampilan } \\
\text { ok }\end{array}$ \\
\hline 2 & Setting & Klik Setting & Tampilan Suara & $\begin{array}{l}\text { Tampilan } \\
\text { ok }\end{array}$ \\
\hline 3 & About & Klik About & $\begin{array}{l}\text { Tampilan } \\
\text { Informasi } \\
\text { Pribadi }\end{array}$ & $\begin{array}{l}\text { Tampilan } \\
\text { ok }\end{array}$ \\
\hline 4 & Exit & Klik Exit & Keluar Aplikasi & $\begin{array}{l}\text { Tampilan } \\
\text { ok }\end{array}$ \\
\hline
\end{tabular}

Gambar 17. Gambar Tabel Pengujian Black Box

\section{Analisis Penelitian}

Penelitian dengan metode kuantitatif menggunakan kuesioner. Pengujian ini bertujuan untuk memastikan apakah game yang dibuat sesuai dengan tujuannya. Pada penelitian ini pengujian dilakukan dengan menggali data kuantitat if dengan menggunakan kuesioner yang terdiri dari 5 soal dan disebarkan pada 6 responden. Adapun daftar pertanyaannya adalah sebagai berikut :

1. Konsep game menarik

2. Tampilan game menarik

3. Game mudah difahami

4. Misi pada game mudah diselesaikan

5. Rintangan yang ada pada game mudah dipecahkan.

Tabel 3.

Rekapitulasi Hasil Kuesioner

\begin{tabular}{|c|c|c|c|c|c|}
\hline Pertanyaan & SS & S & KS & TS & Jumlah \\
\hline 1 & 2 & 2 & 2 & & 6 \\
\hline 2 & 3 & 3 & 1 & 1 & 6 \\
\hline 3 & 2 & 2 & 1 & 1 & 6 \\
\hline 4 & 1 & 3 & 1 & 1 & 6 \\
\hline 5 & 1 & 4 & 1 & & 6 \\
\hline
\end{tabular}

Dari kuesioner yang telah disebar dan rekapitulasi hasil kuesioner (Tabel 3) yang dilakukan kemudian dicari nilai rata-rata. Nilai rata-rata yang diperoleh meliputi aspek ketertarikan, kemanfaatan, kesesuaian kurikulum dan kemudahan. Untuk aspek ketertarikan diambil dari rata-rata hasil kuisioner pertanyaan nomor 1,2,3,4 dan 5 .

Tabel 6.

Rekapitulasi kuesioner aspek ketertarikan

\begin{tabular}{l|c|c|c|c|c|}
\hline \multirow{2}{*}{ Pertanyaan } & \multicolumn{5}{c|}{ Jawaban Skala } \\
\cline { 2 - 7 } & $\begin{array}{c}\text { SS } \\
(20)\end{array}$ & $\begin{array}{c}\text { S } \\
(15)\end{array}$ & $\begin{array}{c}\text { KS } \\
(10)\end{array}$ & $\begin{array}{c}\text { TS } \\
(5)\end{array}$ & Skor \\
\hline Apakah Konsep game menarik? & 40 & 30 & 20 & 0 & 15 \\
Apakah Tampilan game menarik? & 60 & 45 & 10 & 5 & 19.1 \\
Apakah Game mudah difahami? & 40 & 30 & 10 & 5 & 13.3 \\
Apakah Misi pada game mudah diselesaikan & 20 & 45 & 10 & 5 & 12.5 \\
$\begin{array}{l}\text { Apakah Rintangan yang ada pada game mudah } \\
\text { dipecahkan. }\end{array}$ & 20 & 60 & 10 & 0 & 15 \\
& & & & &
\end{tabular}

Rata-rata 14.98

\section{KESIMPULAN DAN SARAN}

Berdasarkan tahapan-tahapan dalam perancangan dan pembuata Advanture Finding Diamond Game Menggunakan Unity 3D Berbasis Android, Maka dapat disimpulkan game yang dibuat secara keseluruhan berdasarkan tingkat pengujian dengan smartphone telah berhasil dijalankan.dan berdasarkan penelitian game ini meningkatkan minat para pengguna game yang mana bisa dinilai dari tingginya hasil pengujian kuantitatif terhadap kuesioner pada jawaban setuju yaitu mencapai

\section{Ucapan Terima Kasih}

Penulis mengucapkan terimakasih kepada Allah SWT. Kedua orang tua, Teman-teman dan Dosen-dosen yang membantu memberi masukan dan arahan untuk menyelesaikan tugas akhir ini.

\section{DAFTAR PUSTAKA}

[1] Zaenal Arifin "Membangun Game Petualangan Sejarah Peninggalan Sunan Kudus Berbasis Android”. Fakultas Teknik, Universitas Muria Kudus.

[2] Analisis Perbandingan Algoritma Dynamic Weighting A* Dan Algoritma Simplified Memory-Bounded A* 
(Sma*)Untuk Mencari Langkah Optimal Dalam Penyelesaian Permainan Peg Solitaire

[3] Marzuki Farandi "Game Berbasis Advanture Sebagai Pendukung Pembelajaran Pengenalan Kata Bahasa Inggris Untuk Anak Usia Dini.

[4] Yeni Winarti “ Perancangan Game Edukasi Petualangan Dengan Tema Who Wants To Be A Milionaire Tingkat Anak SD.

[5] Jainal Winandin " Pembuatan Aplikasi Game The Adventure Of Hard Pada Amikom Surakarta" Amik Citra Darma Surakarta.

[6] Syifaul Fuada “ Perancangan Game Petualangan Pramuka Berbasis Android. Pasca Sarjana S2 Teknik Elektro. Sekolah Tinggi Eknik Elektro Dan Informatika.

[7] Aji Gunadi, Hanif Al Fatta " Analis is Dan Pembuatan Game Petualangan Si Argo Berbasis Flash”. STMIK Amikom Yogyakarta.

[8] Sunarti,Selly, Rahmawati, Dan Setia Wardani “ Pengembangan Game Petualangan Si Bolang Sebagai Media

[9] Pembelajaran Tematik Untuk Meningkatakan Motivasi Dan Prestasi Belajar Siswa Kelas V Sekolah Dasar. FKIP Universitas PGRI Yogyakarta.

[10] I Made Mertha Prayuda, I Putu Agung Bayupati, A. A. Kt. Agung Cahyawan Wiranatha. "Rancang Bangun Game The Adventure Of Timun Mas Berbasis Android.Jurusan Teknologi Informasi, Fakultas Teknik. Universitas Udayana.

[11] Shanggun Dayan "Devlopment Of Design Of Unity Functionality On Android".

[12] Aehyun Kim, Jaehwa Baen " Design And Devlopment Of Smart Game Based On Multilatform (Unity 3D) Game Engine. Tongmyong University.

[13] Shronet Dhuri,Priyanka Zha, Perang Nahete Shreyash Khot \& Prof. Mahavir Devmane "Game Devlopment For Android Device Using Unity 3D".

[14] Abdul Aleem Shaikh "Devlopment Of Dave 3D Andrid Gaming Application".

[15] Alvaro E. Carasco "Acceptability Of An Advanture Video Game In The Treatmen Of Female Adolescents With Symptomp Of Depression”. University Of Chile.

[16] Halff. M. Henry, 2005, Adventure Game For Science Education: Generative.

[17] Thongchai Kaewkiriya "A Design And Devlopment Of Learning Conten For Multimedia Technology Using Multimedia Game "Faculty Of Information Technology, Thai Nichi Institute Of Technology, Bangkok, Thailand

[18] H.Pe Hi And M. Chung "A Computer Adventure Game Applied In E Learning”, International Conference On Intelligent Pervasive Computing, IEEE, 2007, Pp. 446

[19] Creighton, R.H(2010).”Unity 3D Game Development By Example". Packt Publishing.Birmingham. 